\title{
Factors Associated with Hypertension among Elderly in Medan, Indonesia
}

\author{
Santa Ulina Apriani Situngkir1), Namora Lumongga Lubis²), \\ Fazidah Aguslina Siregar3)
}

Masters Program in Public Health, Universitas Sumatera Utara

\begin{abstract}
Background: Hypertension or high blood pressure is often called the silent killer. World Health Organization reported that hypertension is estimated to cause 7.5 million deaths $(12.8 \%$ of the total of all deaths). Prevalence of hypertension in Medan ranked the third in Indonesia in all ages with the mortality of $6.8 \%$. The purpose of this study was to examine factors associated with hypertension among elderly in Medan, Indonesia.

Subjects and Method: This was an analytic observational study with a case-control design. The population was all elderly people who visited community health centre in Medan, North Sumatera, in 2016. A sample of 124 elderly was selected for this study by purposive sampling, consisting of 62 hypertensive and 62 normotensive elderly. The dependent variable was hypertension. The independent variables were physical activity, obesity, and family hisyory of hypertension. Data on blood pressure were measured by sphygmomanometer. The other data were collected by questionnaire. The data were analyzed by a multiple logistic regression.

Results: Obesity ( $\mathrm{OR}=2.48 ; 95 \% \mathrm{CI}=1.05$ to 5.87$)$, low physical activity $(\mathrm{OR}=2.56$; $95 \% \mathrm{CI}=$ 1.06 to 6.17$)$, and family history of hypertension $(\mathrm{OR}=5.74 ; 95 \% \mathrm{CI}=2.44$ to 13.46$)$ increased the risk of hypertension.

Conclusion: Obesity, low physical activity, and family history of hypertension increase the risk of hypertension.
\end{abstract}

Keywords: hypertension, elderly, risk factors

\section{Correspondence:}

Santa Ulina Apriani Situngkir. Masters Program in Public Health, Universitas Sumatera Utara, Jl. Universitas 21, Medan 20115, North Sumatera, Indonesia. Email: situngkir_29@yahoo.com. Mobile: +6281370430295 .

\footnotetext{
BACKGROUND

Hypertension is a non-communicable disease and until now it is still a global health problem. Hypertension is a condition where the systolic blood pressure is > $140 \mathrm{mmHg}$ and the diastolic blood pressure is $>90 \mathrm{mmHg}$ on two measurements with an interval of five minutes in a state of rest. In general, hypertension does not require typical complaints and symptoms so that most of its patients do not realize it. Therefore, hypertension is considered as the silent killer (Bhende et al, 2012).

Based on data from the World Health Organization (WHO) worldwide around
}

972 million people or $26.4 \%$ of people worldwide suffer from hypertension, this number is likely to increase to $29.2 \%$ in 2025. Of the 972 million people with hypertension, 333 million are in developed countries and 639 the rest are in developing countries, including Indonesia (Yonata, 2016). Most diseases in the elderly based on 2013 Basic Health Research are hypertension, with a prevalence of $45.9 \%$ at the age of $55^{-64}$ years, $57.6 \%$ at the age of $65.74 \%$ and $63.8 \%$ at the age of $\geq 75$ years (Ministry of Health, 2016).

Hypertension is the third leading cause of death after stroke and tuberculosis 
Journal of Epidemiology and Public Health (2019), 4(3): 215-221

https://doi.org/10.26911/jepublichealth.2019.04.03.09

in all ages with mortality rates $(6.8 \%)$ from causes of death in all ages in Indonesia (Basic Health Research of RI, 2013).

Indonesia has made several efforts to make people aware of the dangers of hypertension, complications and how to control it by conducting hypertension seminars and early detection of risk factors that are expected to increase community participation and independence in the prevention of hypertension and risk factors, thereby reducing the prevalence of risk factors and prevalence of heart and blood vessel disease, such as stroke and coronary disease in Indonesia. The patients can control hypertension by monitoring blood pressure regularly, stopping smoking, increasing physical activity, consuming high-fiber and low-salt foods. But the fact proves that the control of hypertension is not cured as expected. Many factors must be considered from the patients, health personnel, drugs and health services (Yoga, 2009).

Based on the data of the non-communicable disease (NCD) in Padang Bulan Health Center, it is known that hypertension is a degenerative disease with number 4 out of the 10 biggest diseases in the Padang Bulan Health Center, Medan Baru Subdistrict. The results of the recapitulation of Non-Communicable Diseases in Padang Bulan District Health Center Medan Baru that in 2014, there were 1,425 people with hypertension visits with details of the number of cases in women was 736 people and the number of cases in men was 689 people. In 2015, there were 1,444 people with hypertension consisting of 753 women and 691 men.

\footnotetext{
SUBJECTS AND METHOD

1. Study Design

This study is observational analytic with case-control design (Sastro-asmoro and Ismael, 2016). This research was conducted
}

at Padang Bulan Medan Health Center, in May 2018.

\section{Samples}

The samples consist of 124 subjects selected for this study using purposive sampling.

\section{Instruments}

Data on age, gender, education, and occupation were obtained through interviews and questionnaires. Data on hypertension were obtained by measuring anthropometry, namely the weight of respondents using digital scales and for measuring height using a meter scale.

Data on diet were obtained through the Food Frequenty Questionaire (FFQ) and 24 hour food recall forms. Data on physical activity were obtained through the Physical Activity Level (PAL) questionnaire that was set by FAO / WHO / UNU (2005) and questionnaires made by researchers amounted to 4 items of questions to describe the habits of physical activity carried out by respondents.

\section{Data Analysis}

The data were analyzed using multiple logistic regression.

\section{RESULTS \\ 1. Univariate Analysis \\ Table 1 showed frequency distribution} based on education and occupation. Table 1 showed that the majority of the education of the subjects in the case group and the control group was junior high school, namely 26 people (41.9\%) and 25 people (40.3\%), respectively. Based on the type of job of the respondents, the majority of jobs in the case group were housewives, namely 21 people (33.9\%) and private employees in the control group of 22 people (35.5\%).

\section{Bivariate analysis}

Table 2 showed the results of bivariate analysis. Table 2 shows that the risk of hypertension increases with obesity $(\mathrm{OR}=3.56$; $95 \% \mathrm{CI}=1.69$ to $7.47 ; \mathrm{p}=0.001)$, there is a 
history of hypertension in the family (OR= 7.66; $95 \% \mathrm{CI}=3.44$ to $17.03 ; \mathrm{p}<0.001)$, smoking $(\mathrm{OR}=2.70 ; 95 \% \mathrm{CI}=1.30$ to 5.60 ; $\mathrm{p}=0.007)$, low physical activity $(\mathrm{OR}=4.88$; $95 \% \mathrm{CI}=2.26$ to $10.50 ; \mathrm{p}<0.001)$, high fat consumption $(\mathrm{OR}=2.20 ; 95 \% \mathrm{CI}=1.07$ to $4.51 ; \mathrm{p}=0.032)$.
High carbohydrate consumption $(\mathrm{OR}=1.72$; $95 \% \mathrm{CI}=0.83$ to $3.54 ; \mathrm{p}=0.144)$ and high fiber consumption $(\mathrm{OR}=1.62 ; 95 \% \mathrm{CI}=$ 0.77 to $3.36 ; p=0.196$ ) increased the risk of hypertension but were not statistically significant).

Table 1. Education and occupation frequency distribution

\begin{tabular}{lcccc}
\hline \multicolumn{1}{c}{ Characteristics } & \multicolumn{2}{c}{ Case } & \multicolumn{2}{c}{ Control } \\
\cline { 2 - 5 } Education & $\mathbf{n = 6 2}$ & $\mathbf{0}$ & $\mathbf{6 2}$ & $\mathbf{\%}$ \\
Primary school & & & 11 & 17.7 \\
Jjunior high school & 13 & 21.0 & 25 & 40.3 \\
Senior high school & 26 & 41.9 & 15 & 24.2 \\
College & 16 & 25.8 & 11 & 17.7 \\
Occupation & 7 & 11.3 & & \\
Housewife & & & 16 & 25.8 \\
Retired employee/not working & 21 & 33.9 & 7 & 11.3 \\
Entrepreneur/Merchant & 17 & 6.6 & 17 & 27.4 \\
Private Employee & 20 & 32.4 & 22 & 35.5 \\
\hline
\end{tabular}

\section{Bivariate Analysis}

Table 2. Factors Affecting the Occurrence of Hypertension

\begin{tabular}{|c|c|c|c|c|c|c|}
\hline \multirow{3}{*}{ Variable } & \multicolumn{4}{|c|}{ Hypertension } & \multirow{3}{*}{ OR (95\% CI) } & \multirow[t]{3}{*}{$\mathbf{p}$} \\
\hline & \multicolumn{2}{|c|}{ Yes } & \multicolumn{2}{|c|}{ No } & & \\
\hline & $\mathbf{n}$ & $\%$ & $\mathbf{n}$ & $\%$ & & \\
\hline \multicolumn{7}{|l|}{ Obesity } \\
\hline Yes & 39 & 62.6 & 20 & 32.3 & \multirow{2}{*}{$\begin{array}{c}3.56 \\
\text { (1.69 to } 7.47)\end{array}$} & \multirow[t]{2}{*}{0.001} \\
\hline No & 23 & 37.1 & 42 & 67.7 & & \\
\hline \multicolumn{7}{|c|}{ Family history of hypertension } \\
\hline Yes & 47 & 75.8 & 18 & 29.0 & 7.66 & \multirow[t]{2}{*}{$<0.001$} \\
\hline No & 15 & 24.2 & 44 & 71.0 & (3.44 to 17.03$)$ & \\
\hline \multicolumn{7}{|l|}{ Smoking } \\
\hline Yes & 36 & 58.1 & 21 & 33.9 & 2.70 & \multirow[t]{2}{*}{0.007} \\
\hline No & 26 & 41.9 & 41 & 66.1 & $(1.30$ to 5.60$)$ & \\
\hline \multicolumn{7}{|l|}{ Physical Activity } \\
\hline Lacking & 33 & 53.2 & 36 & 33 & 4.88 & \multirow[t]{2}{*}{$<0.001$} \\
\hline Enough & 29 & 46.8 & 26 & 29 & $(2.26$ to 10.50$)$ & \\
\hline \multicolumn{7}{|c|}{ Carbohydrate Consumption } \\
\hline High & 29 & 46.8 & 21 & 33.9 & 1.72 & \multirow[t]{2}{*}{0.144} \\
\hline Enough & 33 & 53.2 & 41 & 66.1 & (o.83 to 3.54 ) & \\
\hline \multicolumn{7}{|l|}{ Fat Consumption } \\
\hline High & 35 & 56.5 & 23 & 37.1 & 2.20 & \multirow[t]{2}{*}{0.032} \\
\hline Enough & 27 & 43.5 & 39 & 62.9 & (1.07 to 4.51$)$ & \\
\hline \multicolumn{7}{|l|}{ Fiber Consumption } \\
\hline Lacking & 27 & 43.5 & 20 & 32.2 & 1.62 & \multirow[t]{2}{*}{0.196} \\
\hline Enough & 35 & 56.5 & 42 & 67.7 & (o.77 to3.36) & \\
\hline
\end{tabular}

\section{Multivariate Analysis}

Table 3 showed the results of multiple logistic regression analysis. Table 3 showed that hypertension increased with a history of hypertension in the family $(\mathrm{OR}=5.74$; $95 \% \mathrm{CI}=2.44$ to $13.46 ; \mathrm{p}<0.001)$, low 
physical activity $(\mathrm{OR}=2.56 ; 95 \% \mathrm{CI}=1.06$ $95 \% \mathrm{CI}=1.05$ to $5.87 ; \mathrm{p}=0.038)$.

to $6.17 ; \mathrm{p}=0.035)$, and obesity $(\mathrm{OR}=2.48$;

Table 3. The results of multiple logistic regression

\begin{tabular}{|c|c|c|c|c|}
\hline \multirow{2}{*}{ Variable } & \multicolumn{2}{|c|}{$\begin{array}{c}\text { The Incidence of } \\
\text { Hypertension }\end{array}$} & \multirow{2}{*}{$\begin{array}{c}\text { OR } \\
(95 \% \mathrm{CI})\end{array}$} & \multirow[b]{2}{*}{$\mathbf{p}$} \\
\hline & $\begin{array}{l}\text { Cases } \\
n=6 ?\end{array}$ & $\begin{array}{c}\text { Control } \\
n=6 ?\end{array}$ & & \\
\hline \multicolumn{5}{|l|}{ Family History } \\
\hline Yes & 47 & 18 & 5.74 & $<0.001$ \\
\hline No & 15 & 44 & $(2.44-13.46)$ & \\
\hline \multicolumn{5}{|l|}{ Physical Activity } \\
\hline Lack & 27 & 20 & 2.57 & 0.035 \\
\hline Adequate & 35 & 42 & $(1.06-6.17)$ & \\
\hline \multicolumn{5}{|l|}{ Obesity } \\
\hline Yes & 39 & 20 & 2.49 & 0.038 \\
\hline No & 23 & 42 & (1.05 to 5.87$)$ & \\
\hline
\end{tabular}

\section{DISCUSSION \\ 1. The effect of obesity on hyper- tension}

The results showed that obesity affected hypertension. Obese samples were at risk of suffering from hypertension by 3.56 times compared to those who were not obese.

Obesity was a condition of being overweight by $20 \%$ or more of the ideal body weight. Obesity has a positive correlation with hypertension Obesity increased the risk of hypertension and heart disease, because it can increase heart rate and increase blood pressure (Cahyono, 2008).

Epidemiological investigations showed that obesity was the characteristic of a population of hypertensive patients. Cardiac output and blood volume of obese patients with hypertension were higher than those who have normal body weight with equal blood pressure. As a result of obesity, patients tend to suffer from cardiovascular disease, hypertension, and diabetes mellitus (Rohaendi, 2008).

\section{The effect of family history on hypertension}

The results showed that a history of hypertension in the family affected the risk of hypertension. Samples that have a family history of hypertension were 7.65 times more likely to suffer from hypertension compared to samples that did not have a family history of hypertension.

The family boundaries in this study were father, mother, brother or biological sister. If there was a history of hypertension in one of the family members, then someone has the risk of getting hypertension and if there were a lot of family members who have a history of hypertension, then someone has a greater chance of getting hypertension. The result of this study was in accordance with Sulistiyowati (2010), which stated that essential hypertension of $70-80 \%$ was derived by parents.

\section{The effect of smoking on hyper- tension}

The results showed that smoking affected hypertension. Samples who who smoke were at risk of suffering from hypertension by 2.71 times compared to non-smokers.

A study by Rina (2014) reported that there was a relationship between smoking and hypertension. Smokers have a risk of 5.17 times for hypertension compared to non-smokers. This was in accordance with the theory that smoking can lead to an increase in blood pressure. Heavy smokers 
can be associated with an increased incidence of malignant hypertension and the risk of renal artery stenosis which experienced ateriosclerosis due to the accumulation of plaque caused by nicotine contained in cigarettes (Marliani and Tantan, 2005).

\section{The effect of physical activity on hypertension}

The results showed that low physical activity had an effect on hypertension. Low physical activity was at risk of suffering from hypertension by 2.57 times higher than high physical activity.

Good and routine physical activity would train the heart muscle and peripheral resistance which can prevent an increase in blood pressure. In addition, regular exercise can stimulate the release of hormoninin which caused euphoria and muscle relaxation so that blood pressure did not increase. Increasing the intensity of physical activity by 30-45 minutes per day was important as a strategy for prevention and management of hypertension. This study was in line with Anggara (2013), who stated that there was a significant relationship between physical activity and hypertension. Irregular exercise increased the risk of hypertension by 4.41 times higher compared to people who have regular exercise habits.

\section{The effect of carbohydrate con- sumption on hypertension}

The results showed that high carbohydrate consumption affected hypertension. People who consume high carbohydrates were more likely to have hypertension than low carbohydrate consumption.

The results of bivariate analysis showed that carbohydrate consumption was correlated with hypertension $(\mathrm{OR}=$ $1.71 ; \mathrm{p}=0.140$ ).

Carbohydrates can cause hyperlipidemia (the cause of the incidence of athero- sclerosis). This process started from the digestion of carbohydrates which ultimately produce carbon dioxide, water and energy. When energy was not needed, acetyl CoA did not enter the citric acid cycle but it was used to form fatty acids and produce triglycerides. Therefore, restricttions on the consumption of carbon-hydrates also need to be done. It was not a direct cause, but it helped to increase the risk of hypertension. The imbalance between carbohydrate consumption and energy needs, where consumption was too excessive compared to needs or energy use would lead to obesity. Excess energy in the body was stored in the form of fat tissue. Under normal circumstances, fat tissue was deposited in certain places, which were in the subcutaneous tissue and in the intestinal tissue.

\section{The effect of fat consumption on hypertension}

The results showed that fat consumption had an effect on hypertension. People who consume high fat were more likely to have hypertension than low fat consumption.

The results of bivariate analysis showed that fat consumption was correlated with hypertension $(\mathrm{OR}=2.20 ; 95 \%$ $\mathrm{CI}=1.07$ to 4.51 ).

Fat consumption also increased the risk of atherosclerosis which was associated with increased blood pressure. The results of the statistical analysis in this study were in accordance with the results of research done by Sugiharto (2007) in Karanganyar Regency by using a case control study design, it was found that the habit of consuming saturated fat ( $>3$ times per week) proven to be a hypertensive risk factor $(\mathrm{p}=$ o.022). Saturated fats (found in butter, cake, pastry, biscuits, meat products, and creams) have been shown to increase cholesterol levels in the blood. Cholesterol 
that was too high can narrow the arteries, and even clog the blood circulation.

\section{The effect of fiber consumption on hypertension}

The results showed that fiber consumption had an effect on hypertension. People who consume low fiber were more likely to have hypertension than high fiber consumption.

The results of bivariate analysis showed that fiber consumption was correlated with hypertension ( $\mathrm{OR}=1.62 ; 95 \%$ $\mathrm{CI}=0.77$ to $3.36 ; \mathrm{p}=0.196$ ).

The results of this study were in line with the results of research conducted by Baliwati et al. (2004), which showed that the mechanism of the occurrence of high blood pressure was related to the consumption of nutrients, one of them was lack of fiber intake in the daily menu, people who consume less fruits and vegetables usually have an unhealthy lifestyle so they can raise blood pressure. Fiber intake was associated with the occurrence of high blood pressure because fiber intake can help to increase the release of cholesterol through feces by increasing the transit time of food ingredients through the intestine.

\begin{tabular}{l}
\hline REFERENCES \\
\hline Anggraini F (2008). Hubungan antara gaya \\
hidup dan status kesehatan lansia \\
binaan puskesmas Pekayon Jaya Kota \\
Bekasi Tahun 2008. Skripsi. Fakultas \\
Kesehatan Masyarakat: Universitas \\
Indonesia.
\end{tabular}

Agus A, Agoes A, Agus A, Dany F, Nirmala WK (2016). Penyakit di usia tua. Jakarta: Penerbit Buku Kedokteran EGC.

American Heart Association (2010). Heart Disease and Stroke Statistics. http//circ.ahajournal.org/lookup/doi/10.11 61/CIR.0000000000000152.
Baliwati YF, Khomsan A, Dwiriani CM (2004). Pengantar pangan dan gizi. Jakarta: Penebar Swadaya.

Bhende AM, Zade SB, Sitre SR (2012). Influence of family hypertension on blood pressure, serum cholesterol, high liportein cholestrol in general population. Int J Pharm Bio Sci. 3(1): 176-180.

Biro Pusat Statistik (2011). Survei sosial ekonomi nasional. Statistik Penduduk Lanjut Usia. Jakarta.

Cahayono S (2008). Gaya hidup dan penyakit modern. Jakarta: Kanisius.

Darmojo B, Martono H (2010). Buku ajar geriatri, ilmu kesehatan usia lanjut. Jakarta. Fakultas Kedokteran. Universitas Indonesia.

Depkes RI (2013). Gambaran kesehatan lanjut usia di Indonesia. Penerbit Kementrian Kesehatan RI. Jakarta.

FAO/WHO/UNU (2005). Human Energy Requirement, Report of a Joint FAO/ WHO/UNU Expert Consultation.

Hafiz (2016). Faktor-faktor yang berhubungan dengan kejadian hipertensi pada kelompok usia lanjut di wilayah kerja UPT Puskesmas Petang I Kabupaten Bandung, Skripsi Fakultas Kedokteran Udayana.

Kemenkes RI (2014). Pedoman gizi Seimbang.

Lemeshow S, Hosmer DW, Klar J, Lwangga SK (1990). Adequacy of sample size in health studies. World Health Organisation. Chichester: Wiley. http://apps.who.int/iris/bitstream/10665/41607/1/o471925179_eng.pdf.

Ma W, Zhang B, Yang Y, Qi L, Meng L, Zhang Y, Huo Y (2017). Correlating the relationship between interarm systolic blood pressure and cardiovascular disease risk factors. J Clin Hypertens (Greenwich). 19(5): 466471. doi: 10.1111/jch.12987. 
Patil M, Durairaj M (2015). Risk factors of hypertension among adult men: evidence from a real world outcomes investigation in Western Indian Population. International Journal of Advanced Research. 3(7): 274-282.

Murti B (1997). Prinsip dan metode riset epidemiologi. Yogyakarta: Gadjah Mada University.

Nugroho (2008). Keperawatan Gerontik \& Geriatrik, Jakarta: Penerbit Buku Kedokteran EGC.

Padila (2014). Buku Ajar Keperawatan Gerontik, Yogyakarta: Nuha Medika.

Palmer A, William B (2005). Tekanan Darah Tinggi. Jakarta : Erlangga

PDPERSI (2016). Program Pemenuhan Hak Lansia Disiapkan Jelang Bonus Demografi pada 2030.

PERKI (2011). Pedoman pembaharuan American heart association di Indonesia, Jakarta: PB PERKI.

Priyoto (2015). Nursing intervention classification (NIC) dalam keperawatan gerontik. Jakarta: Salemba Medika

Riskesdas (2013). Situasi dan analisis hipertensi, infodatin pusat data dan informasi Kemenkes RI.

Rustika, Riyadina W (2000). Profil penduduk lanjut usia di Indonesia (Analisis Data Susenas 1991). Media Litbang Kesehatan. 10(2).

Khalesi S, Irwin C, Sun J (2017). Dientry patterns, nutritions knowledge and lifestyle: Associations with blood pressure in a sample of Australia Adults. High Blood Press Cardiovasc Prev. 24(4): 453-462. doi: 10.1007/S40292-017-0229-9.

Sastroasmoro S, Ismael S (2016). Dasardasar Metodologi Penelitian Klinis, Jakarta: Sagung Seto.
Saxena DP, Saxena DV, Saxena DY (2011). Bio-social factors associated with hypertension in hilly population of Tehri Garhwal. Indian Journal of Community Health. 23(2): 81-83.

Sirait AM, Yulianti P, Ida LT (2011). Perilaku merokok di Indonesia. Buletin Penelitian Kesehatan. Badan Penelitian dan Pengembangan Kesehatan. $30(3)$.

Szumilas M (2010). Explaining odds ratios. Canadian Academy of Child and Adolescent Psychiatry. J Can Acad Child Adolesc Psychiatry. 19(3): 227-229.

Takasihaeng DGS (2002). Hidup sehat di usia lanjut. Jakarta. Buku. Kompas.

Undang-Undang Kesejahteraan Lansia Republik Indonesia Nomor 13 Tahun 1998.

Undang-Undang Kesehatan Republik Indonesia Nomor 36 Tahun 2009.

Ndip Agbor V, Temgoua MN, Noubiap JJ (2017). Scaling up the use of home blood pressure monitoring in the management of hypertension in lowincome countries: A step towards curbing the burden of hypertention. $\mathrm{J}$ Clin Hypertens (Greenwich). 19(8): 786-789. doi: 10.1111/jch.12999.

Winyningtyas M (2009). Faktor yang mempengaruhi kejadian hipertensi pada laki-laki dewasa di Puskesmas Petang I Kabupaten Bandung Tahun 2009. (Skripsi) Program Kesehatan Universitas Udayana. Denpasar.

WHO (2013). Cardiovaskuler. Country Profiles: Global Report on Cardiovaskuler. 